\title{
The Use of Animated Film Media to Improve the Ability of Writing Short Stories in Elementary School
}

\author{
Nanda Saputra ${ }^{1}$, Irnie Victorynie ${ }^{2}$, Syarifah Rahmi $^{3}$, Syarifah Siregar ${ }^{4}$, Dina \\ Komalasari $^{5}$, Suhendi Syam ${ }^{6}$ \\ ${ }^{1,3}$ Sekolah Tinggi Ilmu Tarbiyah Al-Hilal Sigli, Aceh, Indonesia \\ ${ }^{2}$ Universitas Islam 45 Bekasi, Indonesia \\ ${ }^{4}$ Sekolah Tinggi Agama Islam Tapaktuan, Aceh, Indonesia \\ ${ }^{5,6}$ Universitas Muhammadiyah Buton, Sulawesi Tenggara, Indonesia \\ nandasaputra680@gmail.com,victorynie@gmail.com, syarifahrahmi1643@gmail.com, \\ syarifahsir90@gmail.com,komalasaridina28@gmail.com,syamsuhendi@gmail.com
}

\begin{abstract}
This research originated from the low skills of grade IV SDN (public school) 1 Sigli students in writing short stories. Learning media to write short stories is an alternative means of delivering material to students through animated film media. This study aims to determine the improvement of short story writing skills using animated film media in fourth grade students of SDN 1 Sigli. This research is a classroom action research (CAR) which was conducted in three cycles. Each cycle consists of four stages, namely planning, implementing, observing, and reflecting. The subjects of this study were 24 students of grade IV SDN 1 Sigli, consisting of 12 female students and 12 male students. The data collection technique was done by using tests, observations, and field notes. The data analysis used was a comparative descriptive analysis technique. The results of data analysis showed that the acquisition of student learning outcomes with an average value in cycle I: $60 \%$, cycle II: $80 \%$, and cycle III: $91 \%$. Thus it can be concluded, the use of animated film media can improve students' short story writing skills, and teachers always improve their skills in using instructional media. This can be seen from the cycles obtained by students in each cycle.
\end{abstract}

Keywords

the ability to write short stories, animated filmmedia; elementary school students

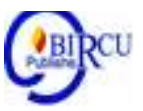

\section{Introduction}

In learning a language, there are four language skills, namely listening, speaking, reading, and writing. Each of these skills is closely related to the other three skills in various ways. In acquiring language skills, we usually go through an orderly relationship. At first, from childhood he learned to listen to the language, speak, learn to read and write. The four skills are basically a unity. Each of these skills is closely related to the thought processes that underlie language. A person's language reflects his thoughts. The more skillful a person is in speaking, the brighter and clearer the way of thinking is. Skills can only be acquired and mastered by practice and lots of practice. Practicing language skills also means practicing thinking skills (Tarigan, 2008:1).

Learning of writing is not enough to be taught manually but must use information and communication technology as an instrument for storing data and publishing various information in order can be used by international community. Published papers must be accountable for its content correctness and its originality. This shows that between writing skills and the skills of using information and communication technology, as well as responsibility which are part of 21 st century skills are interrelated. Writing is also a process 
of critical and creative thinking because writing requires analysis of various choices of words and the process of developing new ideas. Therefore, the activity of writing is closely related to the activity of practicing several 21 st century skills. (Ghofur. et al, 2019)

Of the four skills, writing is something that is found to be very difficult for learners because they have to have many ideas so that they can be expressed in their own essays. Writing is a series of activities for someone to express their thoughts through written language to be read and understood by others. Writing is a complex, productive, and expressive activity. A writer must be skilled at utilizing graphology, language structure and vocabulary. Writing skills will not come automatically, but it must be practiced often and regularly (Tarigan, 2008: 3-4).

Writing skills are an active and productive activity and require an orderly way of thinking which is expressed in written language. Good writing skills are needed by the community 3. Good writing skills are acquired by repeated practice and it takes a long time. Writing is one of the activities that students must face in the learning process, especially for Indonesian language and literature subjects. Through writing activities, it is hoped that students can express their ideas, both scientific and imaginative. As a student, he should have writing skills, which are language skills starting from basic education to tertiary education.

Learning to write is very important taught in elementary schools so that students can be involved in reading and writing activities. This learning is the basis of writing that can determine students in further writing in the next class. Without having adequate writing skills from an early age, students will experience learning difficulties at a later date.

Writing skills are skills that need to be possessed by students because in learning activities in class students cannot be separated from writing activities. Morsey (through Henry Guntur Tarigan, 2014:4), argues that writing skills are a characteristic of an educated person or an educated nation.

According to Dawson (through Henry Guntur Tarigan, 2014:1), one form of practice and training to gain mastery of writing can be done through learning activities. So, writing skills experience a process of growth through practice. To acquire writing skills it is not enough to learn grammar and learn knowledge of writing theory, but rather grow through the training process. Writing skills are not automatically mastered by students, but through regular practice and practice.

Mastery of written language is absolutely necessary for students, but in fact teaching reading and writing skills does not get enough attention. Pelly, (through Haryadi and Zamzami, 2016:75), said that reading and writing lessons, which were lessons and basic exercises, are now getting less attention, both from students and teachers. Writing lessons as one aspect of teaching Indonesian is not taken seriously. As a result, the students' Indonesian language skills are inadequate. Badudu, (through Haryadi and Zamzami, 2016:75), argues that the low quality of students' writing skills is due to the fact that writing teaching is taught at an angle.

The limited access to education is considered to have less impact on elementary school students, one of which is the lack of writing skills, especially writing short stories. Writing is a form of thinking aimed at a specific audience (reader) and due to a special event, thing, or reason. The most important task for a writer is to master the principles of writing and thinking that will help him achieve his writing goals. The most important aspects of the principles or principles of writing are discovery, arrangement / arrangement, and style, Angelo (through Achmadi, 2018:142).

Writing is an activity to convey ideas, thoughts, and feelings in writing so that they can be understood by other people or readers. For this reason, a writer needs to know what to write, what is the purpose of writing, which is the result of writing for, and how to write. 
There are several types of writing that also determine who the readers are, one of which is writing in the form of stories. Gail, (via Enny Zubaidah, 2012:1).

One type of story is a short story which is often shortened to a short story. A short story is a story that gives a single dominant impression about a character in a dramatic setting and situation; short story. The short story must show cohesiveness as a basic benchmark (Zaidan, et al. 2011: 23). Writing is a language skill that is used to communicate indirectly, not face to face with other people. Writing is a productive and expressive activity (Henry Guntur Tarigan, 2014:4). Writing skills cannot be obtained naturally, but through a process of teaching and learning or regular practice (Sabarti Akhadiah, et al. 2011:81). Writing is an activity that is continuous in nature so that learning needs to be carried out continuously since elementary school, it is based on the idea that writing is a basic skill as a provision for learning to write the next level. Learning to write in elementary schools needs optimal attention so that it can meet the expected writing ability targets.

To optimize learning outcomes, especially in the field of writing skills, a learning approach is needed that emphasizes learning activities and students' creativity. An appropriate and planned writing learning plan with effective learning strategies is needed so that students have understanding and writing skills. In order to carry out writing learning in elementary schools, a teacher is required to have the ability to plan and carry out writing learning appropriately, for that a teacher must have an understanding regarding the writing learning approach, how to develop students' writing skills and develop writing.

In teaching the teacher is not just explaining and delivering a number of materials to students. However, teachers should master various teaching methods and be able to manage the class well. Teaching is the process of conveying knowledge to students or students at school, passing on culture to the younger generation through school educational institutions, an environmental organization effort to create learning conditions for students, providing learning guidance to students (Oemar Hamalik, 2011: 44-50). In addition to using various interesting methods, the use of instructional media in the teaching and learning process is an important thing in order to achieve learning goals effectively and efficiently. The use of media aims to make the message or information communicated to the maximum extent possible by students as recipients of information (Soeparno 2018: 5).

Teaching that is full of dynamics in activating students requires learning media that is attractive and continuously innovates. Learning media is very effective in attracting students' interest in learning and knowing something. Media is needed because learning will be better if it involves many senses and students will master the learning outcomes optimally if in student learning it is possible to use as many senses as possible to interact with learning content. According to Soeparno (2018:1), media is a tool that is used as a channel to convey a message or information from a source (resource) to the receiver (receiver). With the media, students not only activate their sense of hearing and listen to the teacher's explanation, but also the senses of sight, taste and so on (Dadan Djuanda, 2016: 102).

Media and good story writing learning techniques have not been widely practiced at the elementary school level, especially learning to write stories at Sigli 1 Elementary School, Pidie District, Pidie Regency. Based on the results of observations in grade IV of SD Negeri 1 Sigli, it was found that the students' skills in writing short stories were still low. From the initial analysis of the students' stories, it can be stated that (a) the theme is less attractive, (b) the story uses a first-person perspective (without presenting a character other than me), (c) the storyline progresses very simply, (d) the setting or the setting of the story is unclear where it took place, when it happened and the atmosphere and circumstances when the story took place, (e) using my character without presenting other characters and the 
characterizations were not well presented, (f) the message of the story was not well presented, and (g) using a narrative style or language style that is not appropriate, the selection, use, and placement and placement of words are not quite right.

Based on the results of interviews conducted by researchers with grade IV teachers of SDN 1 Sigli, it was found that in learning to write short stories the teacher had not maximized and applied the right learning media so that students had difficulty developing ideas and ideas, and in the end students only imitated short stories already available. For beginner short story writers, the teacher should guide students in writing short stories, starting from the stage of generating ideas and ideas, developing ideas and writing up to the stage of writing a short story as a whole. The teacher has also never applied scribe video media to help students come up with ideas and ideas.

Based on the observations of the pre-research stage, information was obtained that in learning Indonesian, especially writing short stories, the teacher only uses the lecture, question and answer and assignment methods. In addition, teachers also do not use media in learning activities. From the description above, it can be concluded that students find it difficult to emerge and develop ideas and ideas. In fact, the emergence of ideas and ideas is a process that must be carried out before writing. The teacher has not used the media especially for learning to write short stories.

This is in accordance with the opinion of Haryadi and Zamzami (2016: 79), which states that at the prewriting stage, a writer carries out several activities, namely finding ideas, determining the title of the essay, determining goals, choosing the form or type of writing, making a framework, and collect materials then develop into a good writing. Nana Sudjana and Ahmad Rivai (2012:2) suggest that learning media can enhance student learning processes in learning and can enhance student learning outcomes. Therefore, media is important in the learning process, including learning to write short stories. The existence of media in learning will make it easier for students to write short stories.

Lack of interest and motivation of students in participating in learning to write short stories also triggers low skills in writing short story essays. Students often complain when asked to write short stories. Students feel that writing short stories is a difficult and tedious task. Lack of interest and motivation is one of the reasons for the low writing skills of students.

Based on the conditions of learning to write short stories in grade IV of SD Negeri 1 Sigli, it can be stated that (1) the teacher has not utilized adequate learning media, (2) the learning technique is not optimal (it is proven that the teacher does not provide adequate explanation), (3) the results of the story Short story students 'work is not good due to the lack of media and learning techniques to write short stories adequately, (4) the students' average results in writing short stories are still low and far from the average, and (5) students have not yet produce a short story that is interesting to read.

One of the efforts that can be made to overcome the above problems is to use animated film media. Therefore, it is necessary to learn to write short stories using animated film media for fourth grade students of SDN 1 Sigli. The author is interested in examining how the use of animated film media as an effort to improve the ability to write short stories in grade IV SDN 1 Sigli as classroom action research. The use of animated film media is expected to increase students' motivation in telling what students observe in animated films in the form of short stories. Students can arrange the stories in the animated film into coherent sentences so as to produce a good short story. In addition, animated film media can also reduce boredom so that students can participate in learning to write short stories actively and enthusiastically. 


\section{Research Methods}

The method used in this research is Classroom Action Research method. The PTK model used in this study was the Spiral model from Kemmis-Mc Taggart (1988). According to Arikunto (2007) classroom action research is a teacher's need to improve their professionalism as a teacher. The reason is (1) CAR is very conducive to making teachers sensitive and responsive to the dynamics of learning in their class. Teachers become reflective and critical of what teachers and students do, (2) CAR improves teacher performance so that it becomes professional. The teacher is no longer a practitioner who has been satisfied with what he has done for years without any improvement and innovation, but he can position himself as a researcher in his field, (3) The teacher is able to improve the learning process through an in-depth assessment of what what happens in his class, and (4) CAR does not interfere with the main duties of a teacher because he does not need to leave his class.

The stages of this research according to Arikunto (2010: 131) are (1) planning; (2) implementation and observation; (3) reflection. The subjects of this study were teachers and fourth grade students of SDN 1 Sigli, totaling 24 students consisting of 12 male students and 12 female students. The location of this research is SDN 1 Sigli.

Data collection techniques in this study were carried out by: (1) observation; (2) test; (3) field notes. This technique is used to describe the implementation of learning, the results of learning Indonesian, describe the obstacles during applying the learning model and how to overcome them.

The assessment instruments used were: (1) learning implementation sheet; (2) sheet of student learning outcomes test; (3) field notes sheet. The learning implementation sheet is used to obtain data about the implementation of learning and achievement. Student learning outcomes test sheets are used to obtain data about student learning outcomes. Field notes are carried out to record constraints that occur during the learning process. Furthermore, the data obtained will be processed and analyzed qualitatively and quantitatively.

The learning implementation data were analyzed quantitatively using the formula:

$P=\frac{F}{N} \times 100 \%$

Information:

$\mathrm{P}=$ percentage number

$\mathrm{F}=$ The percentage of which is being sought

$\mathrm{N}=$ Number of frequencies / number of individuals

To calculate the average (mean) value in this study, the authors use the following formula:

$\bar{X}=\frac{\sum x}{N}$

Information :

$\bar{X}=$ Average (Mean)

$\sum x=$ The sum of all scores

$\mathrm{N}=$ Number of Individuals (Sudjana, 2019:109)

Each student is said to have completed his learning (individual completeness) if the proportion of students' correct answers is $\geq 65$, and a class is said to have completed learning (classical completeness) if in the class there are $\geq 85 \%$ of students who have completed learning. And the Minimum Completeness Criteria score at SDN 1 Sigli is 70. 


\section{Result and Discussion}

\subsection{Action Learning Cycle I}

The evaluation results obtained in Cycle I can be seen in the following table:

Table 1. Acquisition of Evaluation Result Value in Cycle I

\begin{tabular}{|c|c|c|c|}
\hline No. & Student's name & Evaluation Value & Explanation \\
\hline 1 & Ajurni & 90 & Completed \\
\hline 2 & Aula Nazira & 70 & Completed \\
\hline 3 & Hasna Naura & 90 & Completed \\
\hline 4 & Azis Fahrezi & 60 & Not Completed \\
\hline 5 & Alfi Ramadhani & 60 & Not Completed \\
\hline 6 & Khairan Nur & 60 & Not Completed \\
\hline 7 & Muhammad Raziq & 45 & Not Completed \\
\hline 8 & Muhammmad Fadlun & 60 & Not Completed \\
\hline 9 & Muhammad Asra & 70 & Completed \\
\hline 10 & Muhammad Faizul & 65 & Not Completed \\
\hline 11 & Muhammad Ihsan & 80 & Completed \\
\hline 12 & Muhammad Habibi & 90 & Completed \\
\hline 13 & Muhammad Sahar & 60 & Not Completed \\
\hline 14 & Nailatun Izza & 90 & Completed \\
\hline 15 & Naila Al Aura & 60 & Not Completed \\
\hline 16 & Nasyithatul Adzkia & 45 & Not Completed \\
\hline 17 & Nisa Salsabila & 30 & Not Completed \\
\hline 18 & Raisya Jahira & 75 & Completed \\
\hline 19 & Raisya Dinia & 90 & Completed \\
\hline 20 & Reza Alfian & 60 & Not Completed \\
\hline 21 & Syifaul Azkia & 50 & Not Completed \\
\hline 22 & Ulfa Rafika & 85 & Completed \\
\hline 23 & Wildan Zafiri & 75 & Completed \\
\hline 24 & Abdul Azis & 90 & Completed \\
\hline & TOTAL & 1450 & \\
\hline & AVERAGE VALUE & 60,41 & Not good \\
\hline
\end{tabular}

Based on the results shown in table 3.1 above, the lowest value is 30 and the highest score is 90 with details of 1 person who got 30, then 2 people scored 45, 250 people, 2 people scored 65, 60 points 7 people, the value of 70 as many as 2 people, the value of 75 as many as 2 people, the value of 85 as many as 1 person and 90 as many as 5 people, so it has an average value of 60.41 .

The categories of values obtained by each student can be seen from the achievement of students with minimum completeness criteria and classical completeness that the authors tabulate in the following table: 
Table 2. Criteria for grades achieved by Cycle I Students

\begin{tabular}{cccccc}
\hline Cycle & Value & Frequency & Completed & Not Completed & Explanation \\
\hline \multirow{2}{*}{ I } & $>70$ & 11 & $\sqrt{ }$ & & $45,83 \%$ \\
& $<70$ & 13 & & $\sqrt{ }$ & $54,16 \%$ \\
\hline \multicolumn{2}{c}{ Total } & 24 & & & $100 \%$ \\
\hline
\end{tabular}

Based on the results shown in table 3.2 above, the learning outcomes meet the Minimum Completeness Criteria (KKM) only 11 students with a percentage, while students whose learning outcomes do not meet the KKM are 13 students with a percentage of 60.41 .

\subsection{Action Learning Cycle II}

Tabel 3.Value of Cycle II Evaluation Results

\begin{tabular}{|c|c|c|c|}
\hline No. & Student's name & Evaluation Value & Explanation \\
\hline 1 & Ajurni & 60 & Not Completed \\
\hline 2 & Aula Nazira & 60 & \\
\hline 3 & Hasna Naura & 60 & Not Completed \\
\hline 4 & Azis Fahrezi & 60 & \\
\hline 5 & Khairan Nur & 100 & Completed \\
\hline 6 & Muhammad Raziq & 100 & \\
\hline 7 & Muhammad Fadlun & 90 & Completed \\
\hline 8 & Muhammad Asra & 90 & \\
\hline 9 & Muhammad Faizul & 100 & Completed \\
\hline 10 & Muhammad Ihsan & 100 & \\
\hline 11 & Muhammad Habibi & 60 & Not Completed \\
\hline 12 & Muhammad Sahar & 60 & \\
\hline 13 & Nailatul Izza & 60 & Not Completed \\
\hline 14 & Naira Al Aura & 60 & \\
\hline 15 & Nasyithatul Adzkia & 85 & Completed \\
\hline 16 & Nisa Salsabila & 85 & \\
\hline 17 & Raisya Jahira & 80 & Completed \\
\hline 18 & Raisya Dinia & 80 & \\
\hline 19 & Reza Alfian & 85 & Completed \\
\hline 20 & Syifaul Azkia & 85 & \\
\hline 21 & Ulfa Rafika & 90 & Completed \\
\hline 22 & Wildan Zafir & 90 & \\
\hline 23 & Alfi Rahmadani & 90 & Completed \\
\hline 24 & Abdul Azis & 90 & \\
\hline & TOTAL & 1.920 & Good Enough \\
\hline & AVERAGE VALUE & 80 & \\
\hline
\end{tabular}

The table above shows the students' ability in writing short stories, the students experienced an increase, it was seen from the results obtained by students in cycle II, in cycle II only a few groups consisting of 12 people scored below the KKM (Minimum Completeness Criteria) of all students. those who were divided into 12 groups received very good scores. 
Tabel 4. Criteria for scores achieved by students of SDN 1 Sigli in cycle II

\begin{tabular}{|c|c|c|c|c|c|}
\hline Cycle & Value & Frequency & Completed & Not Completed & Explanation \\
\hline \multirow{2}{*}{ II } & $>70$ & 16 & $\sqrt{ }$ & & $66,66 \%$ \\
\hline & $<70$ & 8 & & $\sqrt{ }$ & $33,33 \%$ \\
\hline \multicolumn{2}{|c|}{ Total } & 24 & & & $100 \%$ \\
\hline
\end{tabular}

Based on the results obtained in table 3.4 above, the number of students who experienced learning completeness increased to 16 students with a percentage value of 66.66, while students whose learning outcomes did not complete decreased to 8 students with a percentage value of 33.33 .

\subsection{Action Learning Cycle III}

Tabel 5. Acquisition of Cycle III Student Group Results

\begin{tabular}{clcc}
\hline No. & Student's name & Evaluation Value & Explanation \\
\hline 1 & Ajurni & 85 & Completed \\
2 & Aula Nazira & 85 & \\
\hline 3 & Hasna Naura & 85 & Completed \\
4 & Azis Fahrezi & 85 & \\
\hline 5 & Khairan Nur & 85 & Completed \\
6 & Muhammad Raziq & 100 & \\
\hline 7 & Muhammad Fadlun & 100 & Completed \\
8 & Muhammad Asra & 100 & \\
\hline 9 & Muhammad Faizul Kamal & 100 & Completed \\
10 & Muhammad Ihsan & 100 & Completed \\
\hline 11 & Muhammad Habibi & 80 & Completed \\
12 & Muhammad Sahar & 80 & \\
\hline 13 & Nailatul Izza & 80 & Completed \\
14 & Naira Al Aura & 80 & Completed \\
\hline 15 & Nasyithatul Adzkia & 80 & \\
16 & Nisa Salsabila & 90 & Completed \\
\hline 17 & Raisya Jahira & 90 & \\
18 & Raisya Dinia & 90 & Completed \\
\hline 19 & Reza Alfian & 90 & Completed \\
20 & Syifaul Azkia & 90 & \\
\hline 21 & Ulfa Rafika & 100 & \\
22 & Wildan Zafiri & 100 & \\
\hline 23 & Alfi Rahmadani & 100 & \\
24 & Abdul Azis & 100 & Tood Enough \\
\hline & TOTAL & 90,62 & \\
& AVERAGE VALUE & & \\
\hline & & & \\
\cline { 2 - 3 } & & & \\
\hline
\end{tabular}

Based on the table above, the number of students is 24 , as for the scores obtained by students in cycle III the lowest score is 80 and the highest score is 100 . 
Table 6. Criteria of Value Achieved by Class IV Students of SDN 1 Sigli Cycle III

\begin{tabular}{cccccc}
\hline Cycle & Value & Frequency & Completed & Not Completed & Explanation \\
\hline \multirow{2}{*}{ III } & $>70$ & 24 & $\sqrt{ }$ & & $100 \%$ \\
& $<70$ & 0 & & 0 \\
\hline \multicolumn{2}{c}{ Total } & 24 & & $100 \%$ \\
\hline
\end{tabular}

Based on the results shown in the table above, it can be seen that all students have completed their learning by getting grades that meet the KKM.

\subsection{Cycle I}

Classroom action research (CAR) in cycle I which was carried out at SDN 1 Sigli. Learning is carried out using conventional methods with a total of 24 students. In cycle I most students still do not understand about writing short stories that are taught, it can be seen from the acquisition of evaluation scores that are carried out after learning, namely the lowest score of 30 and the highest score of 90 with details of who got 30 as many as 1 person, then 45 scores as many as 2 people, 50 as many as 2 people, the value of 65 as many as 2 people, the value of 60 as many as 6 people, the value 70 as many as 2 people, the value of 75 as many as 2 people, the value of 85 as many as 1 person and 90 as many as 6 people, so that it has an average value of 60,41 .

So that researchers can conclude that learning in cycle I is less successful and incomplete, but the deficiencies in the learning process in cycle I must be corrected in the next action to be carried out in cycle II so that researchers need to prepare a better plan.

\subsection{Cycle II}

In cycle II, the material presented is about writing short stories, learning which is carried out using animated film media. Based on table 3.2, it is stated that the learning outcomes obtained by students have increased, it can be seen from the results obtained by students in cycle II, the students' ability to write short stories, the students experienced an increase, it was seen from the results obtained by students in cycle II, in cycle Second, there are only a few groups consisting of 2 people who score below the KKM score (minimum completeness criteria). All students who have been divided into several groups get very good scores.

In cycle II, the students' average score was obtained 80, so the researcher concluded that learning using animated film media could improve student learning outcomes because the scores in cycle II were better than the scores obtained by students in cycle I, but the deficiencies in cycle II could be fixed in the cycle. III, to improve in cycle III the researchers made various efforts and approaches in the teaching and learning process on writing short stories at SDN 1 Sigli.

\subsection{Cycle III}

In this cycle the learning atmosphere is very active and fun, there are no more passive students competing in learning because learning uses animated film media and each student can play an active role in the learning process and exchange information with fellow groupmates, this is very easy researchers in explaining the learning material because the students have helped each other in groups, they teach students who do not understand learning and discuss to answer the questions posed by researchers and are active in answering questions in the student worksheet (LKS). 


\section{Conclusion}

Based on the classroom action research activities that have been implemented, it can be concluded that there has been an increase in the skills of writing short stories using animated film media in the fourth grade students of SDN 1 Sigli. The process of increasing learning to write short stories using animated film media, namely: 1) students learn the material of short story elements, 2) students learn language material, 3) students learn how to compile a short story framework based on animated film media, and 4) students write short stories using animated films.

The improvement of short story writing skills was shown in cycle I getting an average score of 60.41 students, in cycle II getting an average score of 80 students and in cycle III getting an average score of 90.62 students. Student activities are more active in learning using animated film media in learning to write short stories in grade IV SDN 1 Sigli.

\section{References}

Agus Suriamiharja, et al. (2016). Petunjuk Praktis Menulis (Practical Instructions for Writing). Jakarta: Depdikbud.

Arikunto, S. (2007). Prosedur Penelitian Suatu Pendekatan Praktik (Research Procedure A Practical Approach). Jakarta: Rineka Cipta.

Dadan Djuanda. (2016). Pembelajaran Bahasa Indonesia Yang Komunikatif dan Menyenangkan (Communicative and Fun Learning Indonesian). Jakarta: Depdiknas, Direktorat Jendral Pendidikan Tinggi. Direktorat Ketenagaan.

Enny Zubaidah. (2012). Peningkatan Kemampuan Mahasiswa dalam Menulis Cerita Anak melalui Strategi Menulis Terbimbing (Improving Student Ability in Writing Children's Stories through Guided Writing Strategies). Jakarta: Program Pasca Sarjana Univeristas Negeri Jakarta.

Ghofur, A. et al. (2019). Teaching Writing and Twenty First Century Skills Using Guided Autonomous Learning Designs. Budapest International Research and Critics InstituteJournal (BIRCI-Journal). P. 495-505.

Hudhana, Winda Dwi dan Agus Sulaeman. (2019). Pengembangan Media Video Scribe dalam Meningkatkan Keterampilan Menulis Cerpen Berbasis Pendidikan Karakter pada Siswa SMA (Development of Scribe Video Media in Improving Character EducationBased Short Story Writing Skills for High School Students). Jurnal Pendidikan Bahasa dan Sastra. Vol. 9, No. 1 Juli 2019.

Haryadi dan Zamzani. (2016). Peningkatan Keterampilan Berbahasa Indonesia (Improvement of Indonesian Language Skills). Yogyakarta: Depdikbud Dirjen Dikti Bagian Proyek Pengembangan Pendidikan Guru Sekolah Dasar.

Nana Sudjana dan Ahmad Rivai. (2012). Media Pengajaran (Teaching Media). Bandung: Sinar Baru Algesindo.

Nana Sudjana. (2019). Penilaian Hasil Proses Belajar Mengajar (Assessment of Teaching and Learning Process Results). Bandung: Remaja Rosda Karya.

Oemar, Hamalik. (2011). Proses Belajar Mengajar (Teaching and learning process). Jakarta: PT Bumi Aksara.

Sabarti Akhadiah, et al. (2011). Bahasa Indonesia I (Indonesian Language I). Jakarta: Depdikbud.

Soeparno. (2018). Media Pengajaran Bahasa (Media Teaching Language). Yogyakarta: PT Intan Pariwara. 
Tarigan, Henry Guntur. (2014). Menulis Sebagai Suatu Keterampilan Berbahasa (Writing as a Language Skill). Bandung: Angkasa.

Tarigan, Henry Guntur. (2008). Menulis Sebagai Suatu Keterampilan Berbahasa (Writing as a Language Skill). Bandung: Angkasa.

Zaidan, et al. (2011). Kamus Istilah Sastra (Dictionary of Literary Terms). Jakarta: Pusat Pembinaan dan Pengembangan Bahasa Departemen Pendidikan dan Kebudayaan. 